\section{OPEN ACCESS}

Edited by:

Evangelos P. Misiakos, National and Kapodistrian University

of Athens, Greece

Reviewed by: Bassem Soliman Hegab, National Liver Institute, Egypt Jan Frank Kukleta,

University of Zurich, Switzerland

*Correspondence:

Ferdinand Köckerling ferdinand.koeckerling@vivantes.de

Specialty section:

This article was submitted to Visceral Surgery,

a section of the journal

Frontiers in Surgery

Received: 05 September 2018 Accepted: 08 November 2018 Published: 27 November 2018

Citation:

Köckerling F (2018) Onlay Technique in Incisional Hernia Repair-A Systematic Review. Front. Surg. 5:71. doi: 10.3389/fsurg.2018.00071

\title{
Onlay Technique in Incisional Hernia Repair-A Systematic Review
}

\section{Ferdinand Köckerling *}

Department of Surgery and Center for Minimally Invasive Surgery, Academic Teaching Hospital of Charité Medical School, Vivantes Hospital, Berlin, Germany

Introduction: A meta-analysis that compared the onlay vs. sublay technique in open incisional hernia repair identified better outcomes for the sublay operation. Nonetheless, an Expert Consensus Guided by Systematic Review found the onlay mesh location useful in certain settings. Therefore, all studies on the onlay technique were once again collated and analyzed.

Materials and Methods: A systematic search of the available literature was performed in August 2018 using Medline, PubMed, Scopus, Embase, Springer Link, and the Cochrane Library. For the present analysis 42 publications were identified as relevant.

Results: In five prospective randomized trials and 17 observational studies the postoperative complication rates ranged between 5 and $76 \%$, with a mean value of $33.5 \%$. The recurrence rates in these studies also ranged between 0 and $32 \%$, with a mean value of $9.9 \%$. Hence, compared with the literature data on the sublay operation, more post-operative complications, in particular wound complications and seroma, with a comparable recurrence rate, were identified.

Conclusion: When the onlay technique is used in certain settings for incisional hernia repair, a careful dissection technique and prophylactic measures (drainage, abdominal binders, fibrin sealant) should be employed to prevent wound complications and seroma formation.

Keywords: incisional hernia, onlay technique, wound complications, surgical site infection, seroma, recurrence

\section{INTRODUCTION}

A meta-analysis that compared the onlay vs. sublay technique (1) in incisional hernia repair on the basis of two prospective randomized trials (RCTs) $(2,3)$, one prospective (4), and seven retrospective studies (5-11) identified significantly fewer surgical site infections and recurrences to the advantage of the sublay technique (1). Likewise, in a Danish registry study, the onlay technique was found to be a significant risk factor for a poorer long-term outcome (12). In one of the two RCTs, onlay mesh reconstruction in the large hernia group provided significantly better results than sublay repair (3). The recurrence rate was lower in the onlay group (12 vs. $20 \%$; $p<0.05)$ (3). In an Expert Consensus Guided by Systematic Review the panel agreed that for open, elective ventral, and incisional hernia repair sublay mesh location is preferred, but onlay mesh location may be useful in certain settings (13). 
This paper now once again critically analyzes the characteristics and findings of the available literature on the onlay technique in incisional hernia repair. To that effect, studies with a mixed patient collective comprising primary ventral hernias and incisional hernias had to be excluded due to significant differences in the outcomes (14-18). Particular attention should be paid to key questions, under which circumstances the onlay technique is advantageous and which factors are impacting the outcome of this technique.

\section{MATERIALS AND METHODS}

A systematic search of the available literature was performed in August 2018 using Medline, PubMed, Scopus, Embase, Springer Link, and the Cochrane Library, as well as a search of relevant journals and reference lists. The following search terms were used: "Incisional hernia," "incisional and ventral hernia," "ventral hernia," "hernia and onlay," "ventral hernia and onlay." The abstracts of 463 publications were screened (Figure 1).

For the present analysis, 42 publications were identified as relevant for the key question. According to the Prisma guidelines (19), a systematic presentation, and synthesis, of the characteristics and findings of the included studies has been made (Tables 1-3).

\section{RESULTS}

\section{Incisional Hernia Repair in Onlay Technique in Meta-Analyses}

A meta-analysis of the Cochrane Library (34) that included two RCTs reporting on only incisional hernias $(35,36)$ did not identify any significant difference between the open onlay and the intraperitoneal onlay mesh (open IPOM) technique.

The meta-analysis by Timmermanns et al. (1) that included two RCTs, one prospective and seven retrospective studies (211) with 775 onlay operations and 1,173 sublay operations in incisional hernia repair observed a trend for recurrence in favor of sublay repair (odds ratio $=2.41 ; 95 \%$ CI $0.99-5.88 ; p=0.05$ ). Surgical site infection occurred significantly less often after sublay repair (odds ratio 2.42; 95\% CI 1.02-5.74; $p=0.05$ ).

No difference was observed regarding seroma and hematoma (1).

\section{Results of Onlay Technique in Incisional Hernia Repair in RCTs}

In the meantime, the findings of five RCTs reporting on the use of the onlay technique in incisional hernia repair are available (Table 1) (2, 3, 20-22). In all RCTs, defect closure was carried out as part of the onlay technique. The wound complication rate

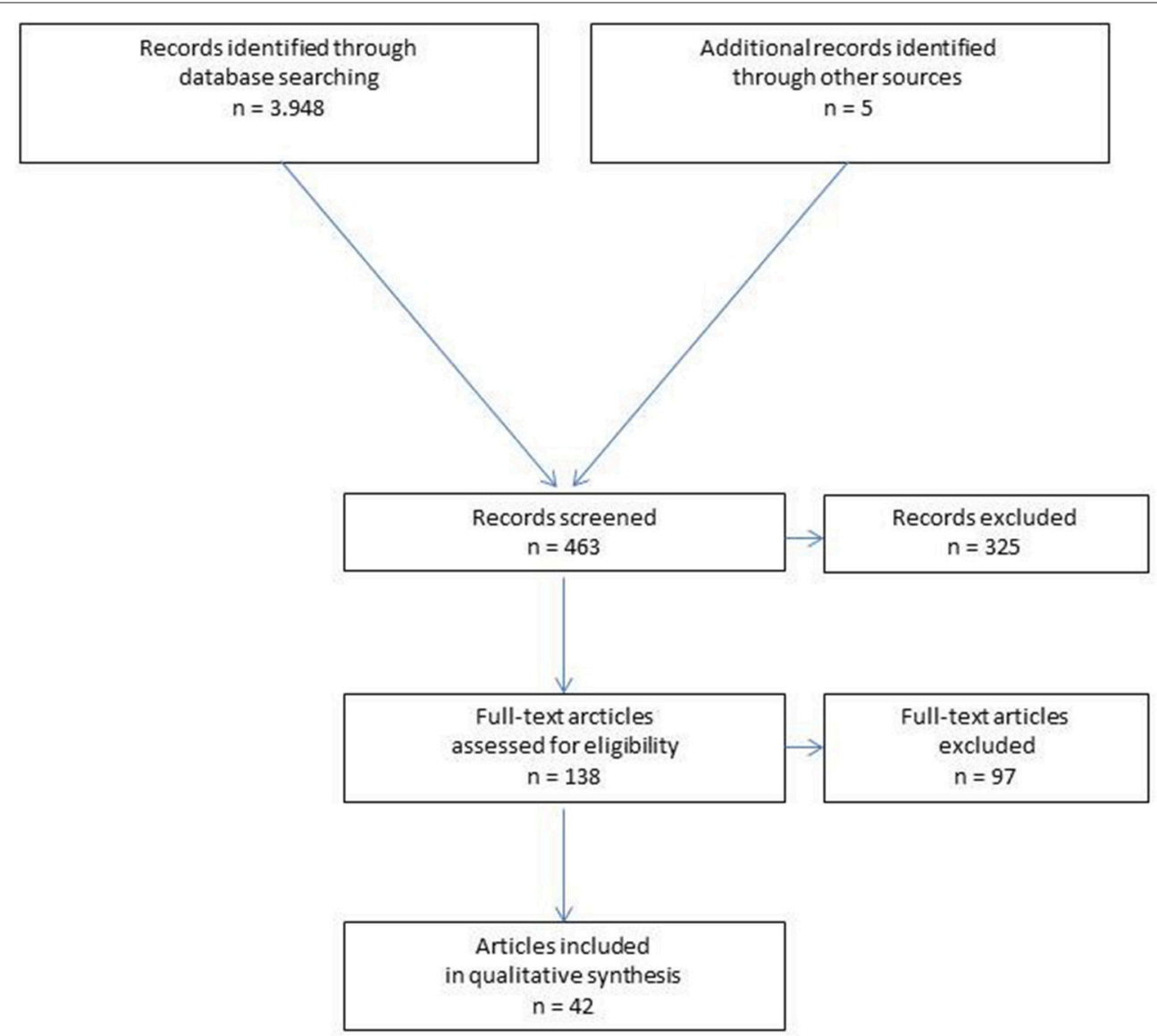

FIGURE 1 | Prisma flow diagram of study inclusion. 
TABLE 1 | Results of onlay technique with defect closure in incisional hernia repair in RCTs.

\begin{tabular}{|c|c|c|c|c|c|c|c|}
\hline References & Patients & $\begin{array}{l}\text { Hernia } \\
\text { type }\end{array}$ & $\begin{array}{l}\text { Inclusion/ } \\
\text { Exclusion }\end{array}$ & Technique & Post-operative complications & Recurrence & Hospital stay \\
\hline Venclauskas et al. (2) & $n=57$ & Incisional & $\begin{array}{l}\text { Male } n=22 \\
\text { female } n=35\end{array}$ & $\begin{array}{l}\text { Defect } \\
\text { closure }\end{array}$ & $\begin{array}{l}\text { Wound complications } 49.1 \% \text {, } \\
\text { Seroma } 45.6 \%\end{array}$ & $\begin{array}{l}10.5 \% \text { after } 12 \text { months } \\
\text { follow-up }\end{array}$ & $5.9 \pm 2.3$ days \\
\hline Weber et al. (3) & $n=224$ & Incisional & Hernia orifice $>25 \mathrm{~cm}^{2}$ & $\begin{array}{l}\text { Defect } \\
\text { closure }\end{array}$ & -- & $\begin{array}{l}12 \% \text { in a } 5 \text { years } \\
\text { follow-up }\end{array}$ & -- \\
\hline Natarajan et al. (20) & $n=13$ & Incisional & $\begin{array}{l}\text { Exclusion of previous } \\
\text { mesh repair }\end{array}$ & $\begin{array}{l}\text { Defect } \\
\text { closure }\end{array}$ & $\begin{array}{l}\text { Seroma } 38.5 \% \text {, } \\
\text { wound infection } 16.7 \%\end{array}$ & -- & -- \\
\hline Sevinc et al. (21) & $n=50$ & Incisional & $\begin{array}{l}\text { Exclusion of patients } \\
\text { with a } \mathrm{BMI}>40\end{array}$ & $\begin{array}{l}\text { Defect } \\
\text { closure }\end{array}$ & Wound complications 24\% & $\begin{array}{l}6 \% \text { with a median } \\
\text { follow-up of } 37.1 \\
\text { months }\end{array}$ & $3.36 \pm 1.9$ days \\
\hline $\begin{array}{l}\text { Demetrashvili et al. } \\
\text { (22) }\end{array}$ & $n=78$ & Incisional & $\begin{array}{l}\text { Exclusion of recurrent } \\
\text { incisional hernias }\end{array}$ & $\begin{array}{l}\text { Defect } \\
\text { closure }\end{array}$ & $\begin{array}{l}\text { Wound complications 50\%, } \\
\text { Seroma } 41 \%\end{array}$ & $\begin{array}{l}5.1 \% \text { in a mean } \\
\text { follow-up of } 4.6 \pm 1.0 \\
\text { years }\end{array}$ & $5.5 \pm 2.7$ days \\
\hline
\end{tabular}

for the onlay technique in all RCTs was between 24 and $49.1 \%$. The most common wound complication was seroma formation as seen in between 38.5 and $45.6 \%$ of cases. Conversely, the recurrence rates were within an acceptable range of between 5.1 and $12 \%$ at follow-up of $1-5$ years.

\section{Results of Onlay Technique for Incisional Hernia Repair in Registries and Multicenter Observational Studies}

In a nationwide prospective study of the Danish Ventral Hernia Database conducted between January 1, 2007 and December 31, 2010, 454 from 3,258 incisional hernias were repaired with onlay technique (12). The cumulative risk of recurrence repair after open and laparoscopic repair was 21.1 and $15.5 \%$, respectively $(p=0.03)$. Younger age, open repair, hernia defects $>7 \mathrm{~cm}$, and onlay mesh positioning in open repair were significant risk factors for poor late outcomes $(p<0.05)$ (12).

In a Swedish study reporting 869 incisional hernia repairs from 40 hospitals the recurrence rate for the onlay technique 12-24 months after surgery was $19.3 \%$ (5).

In a retrospective study of 16 Veterans Affairs Hospitals, 1,346 elective incisional hernia repairs, of which $30 \%$ in onlay mesh technique, were analyzed (37).

Compared with suture repair, the onlay mesh technique did not substantially reduce the recurrence risk (37).

\section{Results of Onlay Technique for Incisional Hernia Repair With Defect Closure in Observational Studies}

The findings of 10 observational studies $(6,23-31)$, which describe defect closure as part of the repair technique, are available on onlay incisional hernia repair. The wound complication rates were reported to be between 5 and $76 \%$, the seroma rates between 9.5 and $72 \%$ and the recurrence rates between 0 and $20.0 \%$ (Table 2). In the study by Tuveri et al. (31) with a very high wound complication rate of $76 \%$ and a seroma rate of $72 \%$, defect closure involved incision of the anterior rectus sheath and the use of a biological mesh. The lowest postoperative complication rate with $5 \%$ and a recurrence rate of
$0 \%$ in a follow-up of 2 years was published by Hopson et al. (28) in incisional hernias with a defect size in width or length not larger than $10 \mathrm{~cm}$ and the use of a self-fixating mesh. A lower post-operative complication rate of $13 \%$ and a recurrence rate of $15 \%$ in a median follow-up time of 35 months (range 4-151 months) was also reported by Anderson et al. (24) in a consecutive series operated by 4 senior surgeons of a single institution.

\section{Results of Onlay Technique for Incisional Hernia Repair Without or With Unknown Defect Closure}

In seven other observational studies $(4,8-11,32,33)$ on the onlay technique in incisional hernia repair, defect closure was not performed or whether defect closure was carried out was not described as part of the surgical technique. In these studies, the wound complication rate was reported to be between 9.1 and $37.8 \%$, seroma rate between 4.5 and $69.2 \%$ and the recurrence rate between 6.1 and $23.1 \%$.

The lowest post-operative complication and recurrence rate in this subgroup was demonstrated in a case series of 354 incisional hernias with a very selected indication for onlay repair (8).

\section{Mean Values of Post-operative Complication and Recurrence Rates}

Overall, on evaluating the results of all studies together the mean value for the post-operative complication rate was $33.5 \%$, with a range from 5 to $76 \%$, and for the recurrence rate it was $9.9 \%$, with a range from 0 to $32 \%$.

\section{DISCUSSION}

In the meta-analysis by Timmermanns et al. (1) comparing sublay vs. onlay incisional hernia repair, fewer surgical site infections as well as recurrences were identified in favor of the sublay technique. That was also confirmed by data from the Danish Hernia Registry (12). Nonetheless, an Expert Consensus Guided by Systematic Review found that, while the sublay operation should be given preference for incisional hernia repair, 
TABLE 2 | Results of onlay technique with defect closure in incisional hernia repair in observational studies.

\begin{tabular}{|c|c|c|c|c|c|c|c|}
\hline References & Patients & $\begin{array}{l}\text { Hernia } \\
\text { type }\end{array}$ & Inclusion/Exclusion & Technique & $\begin{array}{l}\text { Post-operative } \\
\text { complications }\end{array}$ & Recurrence & Hospital stay \\
\hline $\begin{array}{l}\text { Kingsnorth } \\
\text { et al. (23) }\end{array}$ & $n=95$ & Incisional & $\begin{array}{l}31 \% \text { with recurrent } \\
\text { incisional hernia }\end{array}$ & Defect closure & $\begin{array}{l}\text { Post-operative complication } \\
\text { rate } 25 \% \text {, } \\
\text { Seroma rate } 9.5 \% \text {, } \\
\text { wound infection } 8.6 \%\end{array}$ & $\begin{array}{l}3.4 \% \text { after a median } \\
\text { follow-up of } 15.2 \\
\text { months }\end{array}$ & $\begin{array}{l}\text { Mean length of } \\
\text { stay } 6.0 \text { days } \\
\text { (range: } 2-44 \\
\text { days) }\end{array}$ \\
\hline $\begin{array}{l}\text { Andersen } \\
\text { et al. (24) }\end{array}$ & $n=56$ & Incisional & Consecutive patients & Defect closure & $\begin{array}{l}\text { Post-operative complication } \\
\text { rate } 13 \%\end{array}$ & $\begin{array}{l}15 \% \text { in a median } \\
\text { observation time of } 35 \\
\text { months (range: } 4-151 \text { ) }\end{array}$ & -- \\
\hline $\begin{array}{l}\text { Gleysteen } \\
\text { et al. (6) }\end{array}$ & $n=75$ & Incisional & $\begin{array}{l}35 \% \text { recurrent } \\
\text { incisional hernias }\end{array}$ & Defect closure & $\begin{array}{l}\text { Wound complication } \\
21.3 \% \text {, } \\
\text { seroma } 10.7 \% \text {, } \\
\text { wound infection } 12.0 \% \text {, } \\
\text { hematoma } 6.7 \%\end{array}$ & $\begin{array}{l}20.0 \% \text { after a median } \\
\text { follow-up of } 19 \text { months }\end{array}$ & -- \\
\hline $\begin{array}{l}\text { Poelman } \\
\text { et al. (25) }\end{array}$ & $n=101$ & Incisional & $\begin{array}{l}\text { Minimum defect size } \\
10 \times 20 \mathrm{~cm}\end{array}$ & Defect closure & $\begin{array}{l}\text { Wound infection } 21.0 \% \text {, } \\
\text { Seroma } 27.0 \%\end{array}$ & $\begin{array}{l}16 \% \text { with a median } \\
\text { follow-up of } 64 \text { months }\end{array}$ & $\begin{array}{l}4.5 \text { days } \\
\text { (quartiles 3-6.25) }\end{array}$ \\
\hline $\begin{array}{l}\text { Stoikes et al. } \\
\text { (26) }\end{array}$ & $n=50$ & Incisional & $\begin{array}{l}4 \text { patients with prior } \\
\text { mesh procedure }\end{array}$ & $\begin{array}{l}\text { Defect closure, } \\
\text { mesh fibrin glue } \\
\text { fixation }\end{array}$ & $\begin{array}{l}\text { Wound complication } 24 \% \\
\text { Seroma 16\%, }\end{array}$ & $\begin{array}{l}\text { 0\% after a mean } \\
\text { follow-up of } 19.5 \\
\text { months }\end{array}$ & $\begin{array}{l}\text { Mean hospital } \\
\text { stay } 2.9 \text { days } \\
\text { (range: } 0-15 \\
\text { days) }\end{array}$ \\
\hline $\begin{array}{l}\text { Alicuben et al. } \\
\text { (27) }\end{array}$ & $n=22$ & Incisional & $\begin{array}{l}\text { Clean, clean } \\
\text { contaminated and } \\
\text { contaminated cases } \\
\text { included }\end{array}$ & $\begin{array}{l}\text { Defect closure in } 21 \\
\text { cases, bridging in } 1 \\
\text { case, biological } \\
\text { mesh }\end{array}$ & $\begin{array}{l}\text { Wound complication } \\
38.1 \% \text {, } \\
\text { Seroma } 28.6 \% \text {, } \\
\text { wound infection } 9.5 \%\end{array}$ & $\begin{array}{l}4.8 \% \text { (after bridge } \\
\text { repair) in a median } \\
\text { follow-up of } 7 \text { months } \\
\text { (range: } 2-14 \text { ) }\end{array}$ & $\begin{array}{l}\text { Median hospital } \\
\text { stay: } 7 \text { days }\end{array}$ \\
\hline $\begin{array}{l}\text { Hopson et al. } \\
\text { (28) }\end{array}$ & $n=20$ & Incisional & $\begin{array}{l}\text { Defect size width or } \\
\text { length } \geq 10 \mathrm{~cm}\end{array}$ & $\begin{array}{l}\text { Defect closure, } \\
\text { Pro Grip Mesh }\end{array}$ & Wound complication 5\%, & $0 \%$ in 2 years follow-up & $\begin{array}{l}\text { Same day } \\
n=15 \\
\text { next day } n=5\end{array}$ \\
\hline $\begin{array}{l}\text { Gemici et al. } \\
\text { (29) }\end{array}$ & $n=154$ & Incisional & $\begin{array}{l}3 \text { patient underwent } \\
\text { additional } \\
\text { abdominoplasty }(1.9 \%) \\
7.1 \% \text { urgent cases }\end{array}$ & $\begin{array}{l}\text { Defect closure, } \\
\text { full-thickness mesh } \\
\text { fixation }\end{array}$ & $\begin{array}{l}\text { Wound complication } \\
43.7 \% \text {, } \\
\text { seroma } 26.6 \% \text {, } \\
\text { wound infection } 3.2 \%\end{array}$ & $\begin{array}{l}5.2 \% \text { in a median } \\
\text { follow-up of } 54 \text { months } \\
\text { (range: } 12-96 \text { ) }\end{array}$ & $\begin{array}{l}\text { Mean hospital } \\
\text { stay } 4.9 \text { days } \\
\text { (range: } 3-8 \text { ) }\end{array}$ \\
\hline $\begin{array}{l}\text { Juvany et al. } \\
\text { (30) }\end{array}$ & $n=76$ & Incisional & $\begin{array}{l}\text { Exclusion of patients } \\
\text { without } 5 \text {-years } \\
\text { follow-up }\end{array}$ & Defect closure & $\begin{array}{l}\text { Wound complication } \\
18.4 \% \text {, } \\
\text { seroma } 10.5 \% \text {, } \\
\text { wound infection } 2.6 \%\end{array}$ & $\begin{array}{l}32 \% \text { after } 5 \text {-years } \\
\text { follow-up }\end{array}$ & -- \\
\hline $\begin{array}{l}\text { Tuveri et al. } \\
\text { (31) }\end{array}$ & $n=71$ & Incisional & Defect size $>6 \mathrm{~cm}$ & $\begin{array}{l}\text { Defect closure with } \\
\text { incision of the } \\
\text { anterior rectus } \\
\text { sheath, biological } \\
\text { mesh }\end{array}$ & $\begin{array}{l}\text { Wound complication } 76 \% \text {, } \\
\text { seroma } 72 \% \text {, } \\
\text { skin necrosis } 4 \%\end{array}$ & $\begin{array}{l}1.4 \% \text { in a mean } \\
\text { follow-up of } 40 \text { months } \\
\text { (range: } 9-82 \text { months) }\end{array}$ & $\begin{array}{l}\text { Median hospital } \\
\text { stay } 6 \text { days } \\
\text { (range: } 3-12 \text { ) }\end{array}$ \\
\hline
\end{tabular}

the onlay mesh location might be useful in certain settings (13). Therefore, in this present review the available data on the onlay technique in incisional hernia repair were collated in order to compare this method with the sublay technique (38). In this analysis, too, it was revealed that the onlay technique was associated with a higher post-operative complication rate, with a mean value of $33.5 \%$ and range from 5 to $76 \%$, than the sublay technique, with mean value of $18.6 \%$ and range from 8 to $26 \%$ (38). The mean value for the recurrence rate in the onlay technique was $9.9 \%$ with a range from 0 to $32 \%$ and, as such, was comparable with the results of the sublay operation with mean value of $13.5 \%$ and range from 1.6 to $32 \%$ (38). Hence, the main difference between the sublay and the onlay technique was a higher post-operative complication rate to the disadvantage of the onlay technique. Since these complications were generally wound complications and seroma it is thought that they were attributable to the more extensive dissection in the abdominal wall for exposure of the anterior rectus sheath and the anterior abdominal wall fascia for mesh placement in the onlay position (1). Surgical experience, selective indications, and smaller defects seem to reduce the post-operative complication rate $(8,24,28)$. Whether continuous drainage of the wound area in the onlay technique could improve the outcomes cannot be ascertained at present on the basis of the existing literature (39, 40). Therefore, the role of drains in open incisional hernia repair should be investigated in further studies $(39,40)$. Additional preventive measures against post-operative seroma formation in open incisional hernia repair could entail wearing abdominal binders for several weeks and/or the use of low-thrombin fibrin sealant $(41,42)$.

Therefore, future studies on the onlay technique in incisional hernia repair should involve selected indications, a standardized surgical technique by experienced surgeons, paying special attention to ensuring careful dissection in the abdominal wall 
TABLE 3 | Results of onlay technique without or unknown defect closure in incisional hernia repair in observational studies.

\begin{tabular}{|c|c|c|c|c|c|c|c|}
\hline References & Patients & $\begin{array}{l}\text { Hernia } \\
\text { type }\end{array}$ & $\begin{array}{l}\text { Inclusion/ } \\
\text { Exclusion }\end{array}$ & Technique & $\begin{array}{l}\text { Post-operative } \\
\text { complications }\end{array}$ & Recurrence & Hospital stay \\
\hline Kingsnorth et al. (9) & $n=16$ & Incisional & $\begin{array}{l}\text { Lateral and } \\
\text { transverse hernias }\end{array}$ & $\begin{array}{l}\text { Defect closure } \\
\text { unknown }\end{array}$ & $\begin{array}{l}\text { Post-operative complication } \\
31.2 \%\end{array}$ & $\begin{array}{l}6 \% \text { in a follow-up } \\
\text { between } 6 \text { months and } \\
6 \text { years }\end{array}$ & $\begin{array}{l}\text { Mean hospital } \\
\text { stay } 7.9 \text { days } \\
\text { (range: } 6-50 \\
\text { days) }\end{array}$ \\
\hline $\begin{array}{l}\text { de Vries Reilingh } \\
\text { et al. (10) }\end{array}$ & $n=13$ & Incisional & $\begin{array}{l}\text { Large midline } \\
\text { incisional hernias }\end{array}$ & No defect closure & $\begin{array}{l}\text { Post-operative complication } \\
n=17 \\
\text { seroma } 69.2 \% \\
\text { wound infection } 23.1 \% \\
\text { skin necrosis } 23.1 \%\end{array}$ & $\begin{array}{l}23.1 \% \text { in a median } \\
\text { observation time of } \\
19.4 \text { months }\end{array}$ & -- \\
\hline Machairas et al. (32) & $n=43$ & Incisional & $\begin{array}{l}56 \% \text { recurrent } \\
\text { incisional hernias }\end{array}$ & No defect closure & $\begin{array}{l}\text { Wound complication } 21 \% \text {, } \\
\text { seroma } 14 \% \text {, } \\
\text { wound infection } 7 \%\end{array}$ & $\begin{array}{l}9.3 \% \text { in a mean } \\
\text { follow-up of } 54.4 \\
\text { months (range: } 4-106 \\
\text { months) }\end{array}$ & $6-8$ days \\
\hline Coskun et al. (11) & $n=22$ & Incisional & -- & $\begin{array}{l}\text { Defect closure } \\
\text { unknown }\end{array}$ & $\begin{array}{l}\text { Wound complication } \\
22.7 \% \text {, } \\
\text { seroma } 4.5 \% \text {, } \\
\text { wound infection } 9.1 \%\end{array}$ & $13.6 \%$ & $\begin{array}{l}7.9 \text { days (range: } \\
5-11 \text { days) }\end{array}$ \\
\hline Abdollahi et al. (8) & $n=33$ & Incisional & $\begin{array}{l}\text { Emergency cases } \\
\text { excluded }\end{array}$ & $\begin{array}{l}\text { Defect closure } \\
\text { unknown }\end{array}$ & Wound complication $9.1 \%$ & $\begin{array}{l}6.1 \% \text { in a mean } \\
\text { follow-up of } 98 \text { months } \\
\text { (range: } 48-174 \\
\text { months) }\end{array}$ & -- \\
\hline Kumar et al. (4) & $n=45$ & Incisional & -- & $\begin{array}{l}\text { Defect closure } \\
\text { unknown }\end{array}$ & $\begin{array}{l}\text { Wound complication } 37.8 \% \text {, } \\
\text { seroma } 24.44 \% \text {, wound } \\
\text { infection } 13.33 \%\end{array}$ & $\begin{array}{l}10.8 \% \text { in a follow-up of } \\
2-24 \text { months }\end{array}$ & -- \\
\hline Memon et al. (33) & $n=60$ & Incisional & $\begin{array}{l}\text { Defect size } \\
\geq 10 \mathrm{~cm}\end{array}$ & $\begin{array}{l}\text { Defect closure } \\
\text { unknown }\end{array}$ & Surgical site infection $21.7 \%$ & $\begin{array}{l}6.7 \% \text { in a mean } \\
\text { follow-up of } 20.05 \\
\text { months (range: } 12-48 \\
\text { months) }\end{array}$ & -- \\
\hline
\end{tabular}

and to the incorporation of preventative measures against seroma formation.

With regard to the recurrence rate, the onlay technique appears by all means to be comparable with the sublay operation. If the onlay technique outcomes can be improved through technical standardization and the consistent use of measures aimed at reducing the seroma rate, according to the Expert Consensus (13) the onlay technique could indeed be useful in certain settings. Therefore, the onlay technique, should be further investigated in good studies in the future, while focusing in particular on identification of the settings in which the onlay technique has advantages over other surgical procedures.

In conclusion, it must be stated that based on the available literature the onlay compared with the sublay technique in

\section{REFERENCES}

1. Timmermanns L, De Goede B, van Dijk SM, Kleinrensink GJ, Jeekel J, Lange JF. Meta-analysis of sublay versus onlay mesh repair in incisional hernia surgery. Am J Surg. (2014) 207:980-8. doi: 10.1016/j.amjsurg.2013. 08.030

2. Venclauskas L, Maleckas A, Kiudelis M. One-year followup after incisional hernia treatment: results of a prospective randomized study. Hernia (2010) 14:575-82. doi: 10.1007/s10029-0100686-8 incisional hernia repair is associated with markedly more wound complications and seroma rates and with a comparable recurrence rate. Therefore, in the onlay technique the occurrence of wound complications and seroma formation must be prevented through selective indications, surgical experience, careful dissection in the abdominal wall, and prophylactic measures such as drainage, abdominal binders, fibrin sealant. Furthermore, those settings in which the onlay technique has advantages must be better defined.

\section{AUTHOR CONTRIBUTIONS}

FK: literature search, design of study, concept of manuscript, and final submission. 
6. Gleysteen JJ. Mesh-reinforced ventral hernia repair: preference for 2 techniques. Arch Surg. (2009) 144:740-5. doi: 10.1001/archsurg.2009.118

7. Forte A, Zullino A, Manfredelli S. Incisional hernia surgery: report on 283 cases. Eur Rev Med Pharmacol Sci. (2011) 15:644-8.

8. Abdollahi A, Maddah GH, Mehrabi BM, Jangjoo A, Forghani MN, Sharbaf N. Prosthetic incisional hernioplasty: clinical experience with 354 cases. Hernia (2010) 14:569-73. doi: 10.1007/s10029-010-0685-9

9. Kingsnorth AN, Sivarajasingham N, Wong S, Butler M. Open mesh repair of incisional hernias with significant loss of domain. Ann R Coll Surg Engl. (2004) 86:363-6. doi: 10.1308/147870804236

10. De Vries RTS, van Geldere D, Langenhorst B, de Jong D, van der Wilt GJ, van Goor $\mathrm{H}$, et al. Repair of large midline incisonal hernias with polypropylene mesh: comparison of three operative techniques. Hernia (2004) 8:56-9. doi: 10.1007/s10029-003-0170-9

11. Coskun M, Peker Y, Tatar F, Cin N, Kar H, Kahya MC. Median incisional hernia and the factors affecting the recurrence of median incisional hernia repair. Erciyes Tip Dergisi (2009) 31:244-9.

12. Helgstrand F, Rosenberg J, Kehlet H, Jorgensen LN, Bisgaard T. Nationwide prospective study of outcomes after elective incisional hernia repair. J Am Coll Surg. (2013) 216:217-28. doi: 10.1016/j.jamcollsurg.2012.10.013

13. Liang MK, Holihan JL, Itani K, Alawadi ZM, Flores Gonzalez JR, Askenasy EP. Ventral heria management - expert consensus guided by systematic review. Ann Surg. (2017) 265:80-9. doi: 10.1097/SLA.0000000000001701

14. Kroese LF, Gillion JF, Jeekel J, Kleinrensink GJ, Lange JF, HerniaClub Members. Primary and incisional ventral hernias are different in terms of patient characteristics and postoperative complications - a prospective cohort study of 4,565 patients. Int J Surg. (2018) 51:114-9. doi: 10.1016/j.ijsu.2018.01.010

15. Köckerling F, Schug-Paß C, Adolf D, Reinpold W, Stechemesser B. Is pooled data analysis of ventral and incisional hernia repair acceptable? Front Surg. (2015) 2:15. doi: 10.3389/fsurg.2015.00015

16. Stirler VM, Schoenmaeckers EJ, de Haas RJ, Raymakers JT, Rakic S. Laparoscopic repair of primary and incisional ventral hernias: the differences must be acknowledged - a prospective cohort analysis of 1,088 consecutive patients. Surg Endosc. (2014) 28:891-5. doi: 10.1007/s00464-013-3243-6

17. Subramanian A, Clapp ML, Hicks SC, Awad SS, Liang MK. Laparoscopic ventral hernia repair: primary versus secondary hernias. J Surg Res. (2013) 181:e1-5. doi: 10.1016/j.jss.2012.06.028

18. Kurian A, Gallagher S, Cheeyandira A, Josloff R. Laparoscopic repair of primary versus incisional ventral hernias: time to recognize the differences? Hernia (2010) 14:383-7. doi: 10.1007/s10029-010-0649-0

19. Liberati A, Altman D, Tetzlaff J, Mulrow C, Gotzsche PC, Ioannidis J, et al. The PRISMA statement for reporting systematic reviews and meta-analyses of studies that evaluate health care interventions: explanation and elaboration. $J$ Clin Epidemiol. 62:e1-34. doi: 10.1016/j.jclinepi.2009.06.006

20. Natarajan S, Meenaa S, Thimmaiah KA. A randomized prospective study to evaluate preperitoneal mesh repair versus onlay mesh repair and laparoscopic IPOM in incisional hernia surgery. Indian J Surg. (2017) 79:96-100. doi: 10.1007/s12262-015-1430-5

21. Sevinc B, Okus A, Ay S, Aksoy N, Karahan Ö. Randomized prospective comparison of long-term results onlay and sublay mesh repair techniques for incisional hernia. Turk J Surg. (2018) 34:17-20. doi: 10.5152/turkjsurg.2017.3712

22. Demetrashvili Z, Pipia I, Loladze D, Metreveli T, Ekaladze E, Kenchadze $\mathrm{G}$, et al. Open retromuscular mesh repair versus onlay technique of incisional hernia: a randomized controlled trial. Int J Surg. (2017) 37:65-70. doi: 10.1016/j.ijsu.2016.12.008

23. Kingsnorth AN, Shahid MK, Valliattu AJ, Hadden RA, Porter CS. Open onlay mesh repair for major abdominal wall hernias with selective use of components separation and fibrin sealant. World J Surg. (2008) 32:26-30. doi: 10.1007/s00268-007-9287-9

24. Andersen LP, Klein M, Gögenur I, Rosenberg J. Long-term recurrence and complication rates after incisional hernia repair with the open onlay technique. BMC Surg. (2009) 9:6. doi: 10.1186/1471-2482-9-6

25. Poelman MM, Langenhorst B, Schellekens JF, Schreurs WH. Modified onlay technique for the repair of the more complicated incisional hernias: single-centre evaluation of a large cohort. Hernia (2010) 14:369-74. doi: 10.1007/s10029-010-0646-3
26. Stoikes N, Webb D, Powell B, Voeller G. Preliminary report of a sutureless onlay technique for incisional hernia repair using fibrin glue alone for mesh fixation. Am Surg. (2013) 79:1177-80.

27. Alicuben ET, DeMeester SR. Onlay ventral hernia repairs using procine non-cross-linked dermal biologic mesh. Hernia (2014) 18:705-12. doi: 10.1007/s10029-013-1054-2

28. Hopson SB, Miller LE. Open ventral hernia repair using ProGrip ${ }^{\text {TM }}$ selfgripping mesh. Int J Surg. (2015) 23:137-40. doi: 10.1016/j.ijsu.2015.09.069

29. Gemici K, Acar T, Baris S, Yildiz M, Sever C, Bilgi M, et al. Lower recurrence rate with full-thickness mesh fixation in incisional hernia repair. Hernia (2015) 19:927-33. doi: 10.1007/s10029-015-1355-8

30. Juvany M, Hoyuela C, Carvajal F, Trias M, Martrat A, Ardid J. Long-term follow-up (at 5 years) of midline incisional hernia repairs using a primary closure and prosthetic onlay technique: recurrence and quality of life. Hernia (2018) 22:319-24. doi: 10.1007/s10029-018-1730-3

31. Tuveri M, Tuveri A, Nicolò E. Repair of large abdominal incisional hernia by reconstructing the midline and use of an onlay on biological material. Am J Surg. (2011) 202:e7-11. doi: 10.1016/j.amjsurg.2010. 06.005

32. Machairas A, Misiakos E, Liakakos T, Karatzas G. Incisional hernioplasty with extraperitoneal onlay polyester mesh. Am Surg. (2004) 70:726-9.

33. Memon AA, Khan A, Zafar H, Murtaza G, Zaidi M. Repair of large and giant incisional hernia with onlay mesh: perspective of a tertiary care hospital of a developing country. Int J Surg. (2013) 11:41-5. doi: 10.1016/j.ijsu.2012. 11.006

34. den Hartog D, Tulnebreijer WE. Open surgical procedures for incisional hernias. Cochrane Database Syst Rev. (2008) 16:CD006438. doi: 10.1002/14651858.CD006438

35. Köhler I, Sauerland S, Meyer A, Saad S, Schüller BK, Knaebel HP, et al. Mesh implantation in onlay or sublay-technique for closure of median ventral hernias: first results of a randomized clinical trial. In: Poster Presented at the Congress of the German Surgical Association. Munich (2005).

36. Baracs J, Wéber G, Takacs I, Horváth ÖP. Results of open mesh versus suture repair in treatment of abdominal wall hernias (multicentric, prospective, randomized, internet-based clinical trial). In: Poster 29th International Congress of the European Hernia Society (Athens) (2007).

37. Hawn MT, Snyder CW, Graham LA, Gray SH, Finan KR, Vick CC. Long-term follow-up of technical outcomes for incisional hernia repair. J Am Coll Surg. (2010) 210: 648-57. doi: 10.1016/j.jamcollsurg.2009.12.038

38. Köckerling F, Schug-Pass C, Scheuerlein H. What is the current knowledge about sublay/retro-rectus repair of incisional hernias? Front Surg. (2018) 5:47. doi: 10.3389/fsurg.2018.00047

39. Gurusamy KS, Allen VB. Wound drains after incisional hernia repair. Cochrane Database Syst Rev. (2013) 12:CD005570. doi: 10.1002/14651858.CD005570.pub2

40. Krpata DM, Prabhu AS, Carbonell AM, Haskins UN, Phillips S, Poulouse BK, et al. Drain placement does not increase infectious complications after retromuscular ventral hernia repair with synthetic mesh: an AHSQC analysis. J Gastrintest Surg. (2017) 21:2083-9. doi: 10.1007/s11605-017-3601-0

41. Rothman JP, Gunnarsoon U, Bisgaard T. Abdominal binders may reduce pain and improve physical function after major abdominal surgery - a systematic review. Dan Med J. (2014) 61: A4941.

42. Köhler G, Koch OO, Antoniou SA, Lechner M, Mayer F, Emmanuel K. Prevention of subcutaneous seroma formation in open ventral hernia repair using a new low-thrombin fibrin sealant. World J Surg. (2014) 38:2797-803. doi: $10.1007 / \mathrm{s} 00268-014-2691-\mathrm{z}$

Conflict of Interest Statement: The author declares that the research was conducted in the absence of any commercial or financial relationships that could be construed as a potential conflict of interest.

Copyright (c) 2018 Köckerling. This is an open-access article distributed under the terms of the Creative Commons Attribution License (CC BY). The use, distribution or reproduction in other forums is permitted, provided the original author(s) and the copyright owner(s) are credited and that the original publication in this journal is cited, in accordance with accepted academic practice. No use, distribution or reproduction is permitted which does not comply with these terms. 